\title{
Submarine rudder stern-plane configuration for optimum manoeuvring
}

\author{
Ketut Suastika ${ }^{1, *}$, Putri Virliani ${ }^{2}$, and Wasis D. Aryawan ${ }^{1}$ \\ ${ }^{1}$ Department of Naval Architecture, ITS Surabaya, 60111 Surabaya, Indonesia \\ ${ }^{2}$ LHI BPPT, 60111 Surabaya, Indonesia
}

\begin{abstract}
The purpose of the present study is to investigate submarine rudder stern-plane configuration to obtain optimum manoeuvring characteristics. Three configurations are investigated:,$+ x$ and $y$ configuration. The equations of motions were derived with the external forces and moments consist of contributions due to the hydrostatics, hydrodynamics and propeller thrust. To obtain the hydrodynamic coefficients and the hydrodynamic derivatives, the lift and drag were calculated using computational fluid dynamics (CFD). The equations of motions were numerically integrated using Eulerian method to obtain the turning circle. Results of the calculations show that the $\mathrm{x}$-configuration gives the smallest tactical diameter, transfer and advance, which is considered as the most optimum rudder stern-plane configuration.
\end{abstract}

\section{Introduction}

A submarine is expected to have a good manoeuvring performance for the achievement of her mission. One requirement is the ability to dive quickly to a certain depth. The other is the ability to manoeuvre extremely to avoid a mine or torpedo attack. The rudder stern-plane configuration particularly plays a key role in determining the submarine manoeuvring capability [1].

A midget submarine [2] is considered in the present study as illustrated in Fig. 1. The submerged displacement of a midget submarine is usually less than 150 ton. The principal particulars of the midget submarine are summarized in Table 1.

Earlier studies have considered similar object as considered in the present study. Erwandi et al. [3] studied the hydrodynamic forces working on the submarine while manoeuvring. Utina et al. [4] performed experiments on hydroplanes to study the hydrodynamic forces and moments for which a modified design of U-209 submarine was considered.

The present study pursues the earlier studies as reported in $[3,4]$. The purpose of the present study is to investigate the manoeuvring performance of the submarine for which three different rudder stern-plane configurations are considered: + , $\mathrm{x}$ and $\mathrm{y}$ configuration, as shown in Fig. 2.

"Corresponding author: k_suastika@na.its.ac.id 


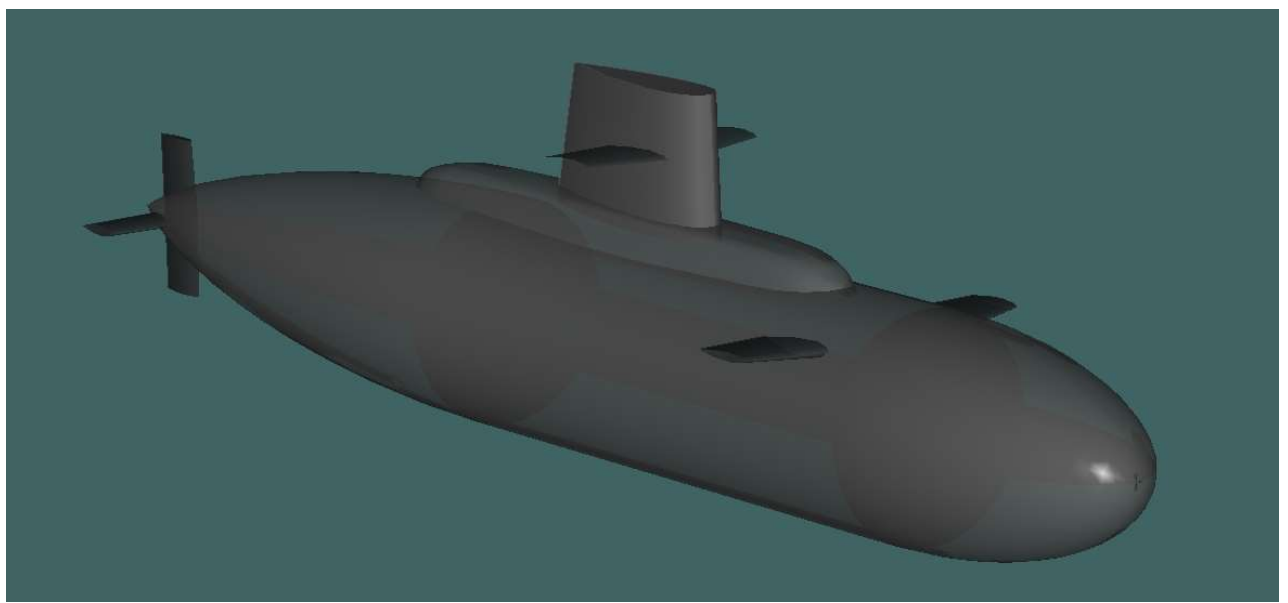

Fig 1. Midget submarine considered in the present study with + rudder stern-plane configuration.

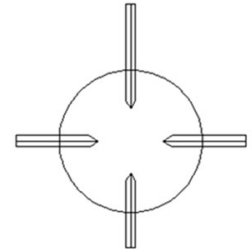

(a)

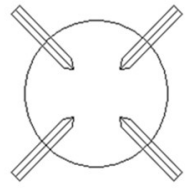

(b)

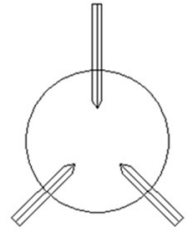

(c)

Fig. 2. Submarine rudder-stern plane configurations: +-stern (a), x-stern (b) and y-stern (c).

Table 1. Principal particulars of the midget submarine.

\begin{tabular}{|l|r|}
\hline LOA & $22.00 \mathrm{~m}$ \\
\hline Diameter & $3.00 \mathrm{~m}$ \\
\hline Draft & $2.60 \mathrm{~m}$ \\
\hline Maximum speed & $14 \mathrm{kn}$ \\
\hline Displacement (surfaced) & $113.90 \mathrm{t}$ \\
\hline Displacement (submerged) & $129.30 \mathrm{t}$ \\
\hline Volume of displacement (surfaced) & $111.17 \mathrm{~m}^{3}$ \\
\hline Volume of displacement (submerged) & $126.14 \mathrm{~m}^{3}$ \\
\hline
\end{tabular}

\section{Method}

The equations of motions were derived with the external forces and moments consist of contributions due to the hydrostatics, hydrodynamics and propeller thrust. Subsequently, the equations of motions are numerically integrated to obtain the turning circles of the submarine for the different variations of rudder stern-plane configurations.

\subsection{Equations of motions}


The submarine motion consists of translation respectively in the $x, y$ and $z$ direction (surge, sway, heave) and rotation respectively about the $x, y$ and $z$ axis (roll, pitch, yaw/drift), which make a 6-degrees of freedom (DOF) motion. The notations used for the motions, forces and moments, together with the local coordinate system moving with the boat are shown in Fig. 3 . The origin $\mathrm{O}$ of the local coordinate system $(x, y, z)$ is located at the centre of buoyancy of the boat (for a fully submerged boat, the centre of buoyancy is fixed).

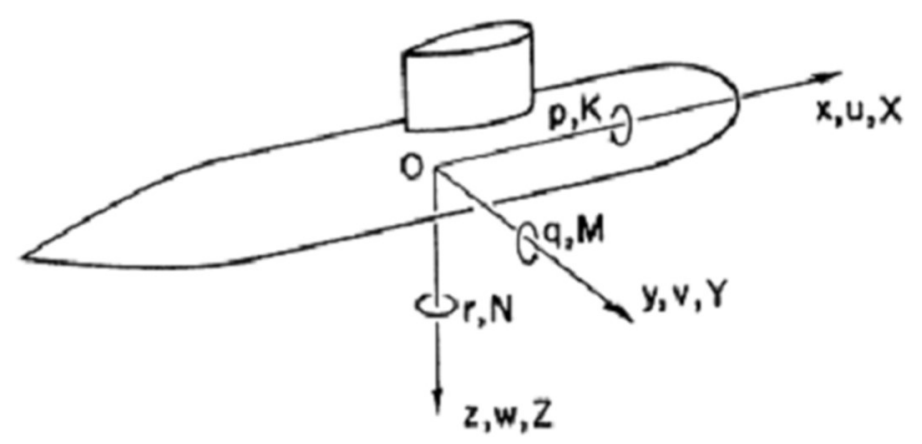

Fig. 3. Local coordinate system and notations for the motions [5].

Using the notations shown in Fig. 3, the equations of motions can be represented as follows:

$$
\begin{aligned}
& {\left[\begin{array}{cccccc}
m-X_{\dot{u}} & 0 & 0 & 0 & m z_{G} & -m y_{G} \\
0 & m-Y_{\dot{v}} & 0 & -m z_{G} & 0 & m x_{G}-Y_{\dot{r}} \\
0 & 0 & m-Z_{\dot{w}} & m y_{G} & -m x_{G}-Z_{\dot{q}} & 0 \\
0 & -m z_{G} & m y_{G} & I_{x}-K_{\dot{p}} & 0 & 0 \\
m z_{G} & 0 & -m x_{G}-M_{\dot{w}} & 0 & I_{y}-M_{\dot{q}} & 0 \\
-m y_{G} & -m z_{G}-N_{\dot{v}} & 0 & 0 & 0 & I_{Z}-N_{\dot{r}}
\end{array}\right] .} \\
& {\left[\begin{array}{c}
\dot{u} \\
\dot{v} \\
\dot{w} \\
\dot{p} \\
\dot{q} \\
\dot{r}
\end{array}\right]=\left[\begin{array}{c}
\Sigma \mathrm{X}_{\text {ext }} \\
\Sigma \mathrm{Y}_{\text {ext }} \\
\Sigma \mathrm{Z}_{\text {ext }} \\
\Sigma \mathrm{K}_{\text {ext }} \\
\Sigma \mathrm{M}_{\text {ext }} \\
\Sigma \mathrm{N}_{\text {ext }}
\end{array}\right]}
\end{aligned}
$$

where $m$ is the mass of the boat, $I_{x}, I_{y}$ and $I_{z}$ are the moment inertia's about the $x, y$ and $z$ axis, respectively, $X_{\dot{u}}, Y_{\dot{v}}, Z_{\dot{w}}, K_{\dot{p}}, M_{\dot{q}}, N_{\dot{r}}, Y_{\dot{r}}, Z_{\dot{q}}, M_{\dot{w}}$ and $N_{\dot{v}}$ are added masses. The external forces and moments on the right-hand side of eq. (1) consist of contributions due to the hydrostatics, hydrodynamics and propeller thrust.

The hydrostatic forces consist of weight and buoyancy, which make an equilibrium. The buoyancy is calculated using the software Maxsurf. The buoyancy force is equal to the weight of the boat $(1268379.29,1268992.70$ and $1267846.36 \mathrm{~N}$ for the,$+ \mathrm{x}$ and $\mathrm{y}$-stern, respectively).

The hydrodynamic forces consist of added masses, drag and lift. The longitudinal and transversal added masses are calculated using the strip theory [6]. The rolling added mass is calculated using the formula given in [7]. The drag and lift are calculated using computational 
fluid dynamics [8]. The CFD results for the drag and lift are used to calculate the hydrodynamic coefficients.

The propeller thrust is calculated using an empirical formula given in [9].

The hydrodynamic derivatives required for the calculation of the turning circle are calculated using the formula given in $[10,11]$.

Results of the calculations of the added masses, drag, lift, thrust and hydrodynamic derivatives described above can be found in [12].

\subsection{CFD calculations for the drag and lift}

CFD simulations were performed to calculate the drag and lift of the submarine. The computational domain is defined as follows [13]. The inlet located at $1.5 \mathrm{~L}$ upstream from the model, where $L$ is the length overall of the boat, is defined as the flow velocity equalling the boat's speed (in the simulation the boat is at rest while the water flows). The outlet located at 3.0 $\mathrm{L}$ downstream from the model is defined as the pressure equalling the undisturbed hydrostatic pressure. The boundary conditions at the bottom wall $(9.0 \mathrm{D}$ below the model, where $D$ is the boat's diameter), top wall (9.0 D above the model) and side walls $(9.0 \mathrm{D}$ aside the model) are defined as free slip while at the surface of the boat as no-slip.

The turbulence model used is the shear-stress transport model [14]. The model gives accurate predictions of the onset and the amount of flow separation [15].

Grid independence tests were performed to ensure that the simulation results do not depend on the number of cells (elements) used in the calculations. The grid independence criterion is defined as the difference between two subsequently calculated drags is less than $2 \%$ where the number of cells used in the latter simulation is approximately twice the number of cells used in the former simulation $[16,17]$.

As criterion for the convergence of the numerical solutions, the root mean squared (rms) error criterion is used with residual target value of $10^{-5}$.

The simulations were run in 64-bit OS stand-alone computer with Intel ${ }^{\circ}$ Core i7-4770 CPU@3.40 GHz processor and 8.00 GB installed memory (RAM).

The drag calculated from the CFD is verified using experimental data obtained from towing tests $[3,4]$. Figure 4 shows a comparison between the drag calculated from CFD and experimental data for the + rudder stern-plane configuration. Figure 4 shows that the CFD underestimates slightly the experimental data. The mean absolute percentage error is $2.8 \%$, indicating a good agreement between the CFD results and the experimental data.

After verifying the CFD results with the available experimental data, the drag and lift coefficients for each rudder stern-plane configuration are calculated for boat's speed of 14 knots (maximum target speed) with varying rudder angle $(\delta r)$ and drift/yaw angle $(\beta)$. The rudder angle $\delta \mathrm{r}$ is varied from $0^{\circ}$ to $35^{\circ}$ with interval of $5^{\circ}$ and the drift angle $\beta$ is varied from $0^{\circ}$ to $20^{\circ}$ with interval also of $5^{\circ}$, as shown in Table 2 .

Table 2. Variations of drift angle $\beta$ and rudder angle $\delta \mathrm{r}$ in the calculation of drag and lift using CFD.

\begin{tabular}{|c|c|}
\hline$\beta\left[^{\circ}\right]$ & $\delta \mathrm{r}\left[{ }^{\circ}\right]$ \\
\hline 0 & $0,5,10,15,20,25,30,35$ \\
\hline 5 & $0,5,10,15,20,25,30,35$ \\
\hline 10 & $0,5,10,15,20,25,30,35$ \\
\hline 15 & $0,5,10,15,20,25,30,35$ \\
\hline 20 & $0,5,10,15,20,25,30,35$ \\
\hline
\end{tabular}




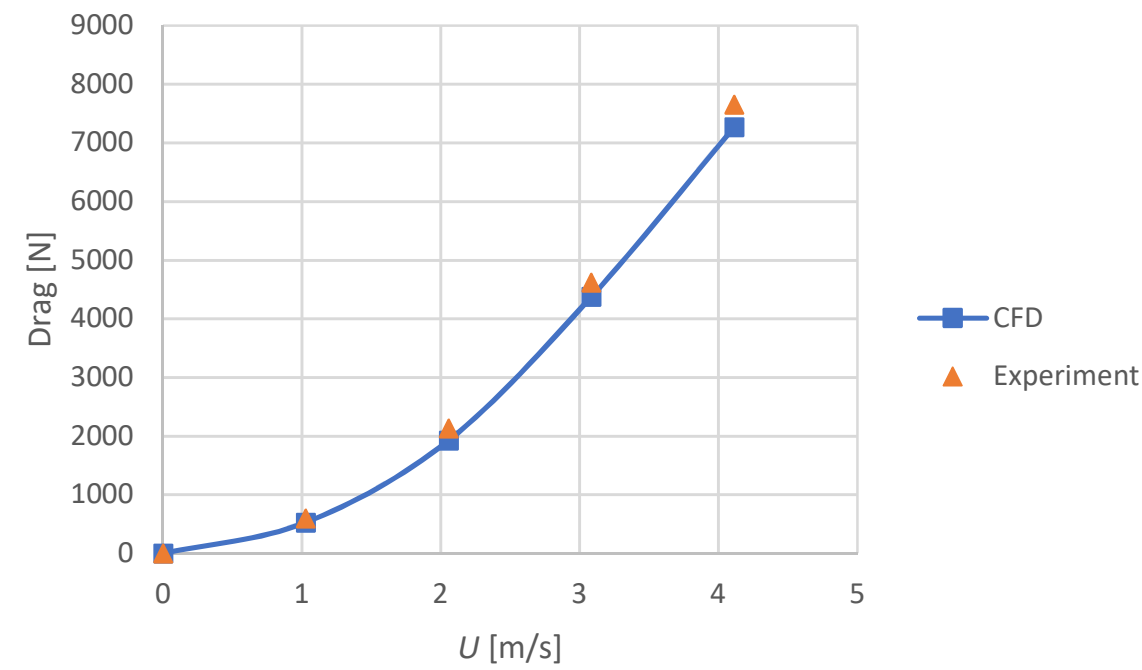

Fig. 4. Drag calculated from CFD compared with experimental data for the + rudder stern-plane configuration.

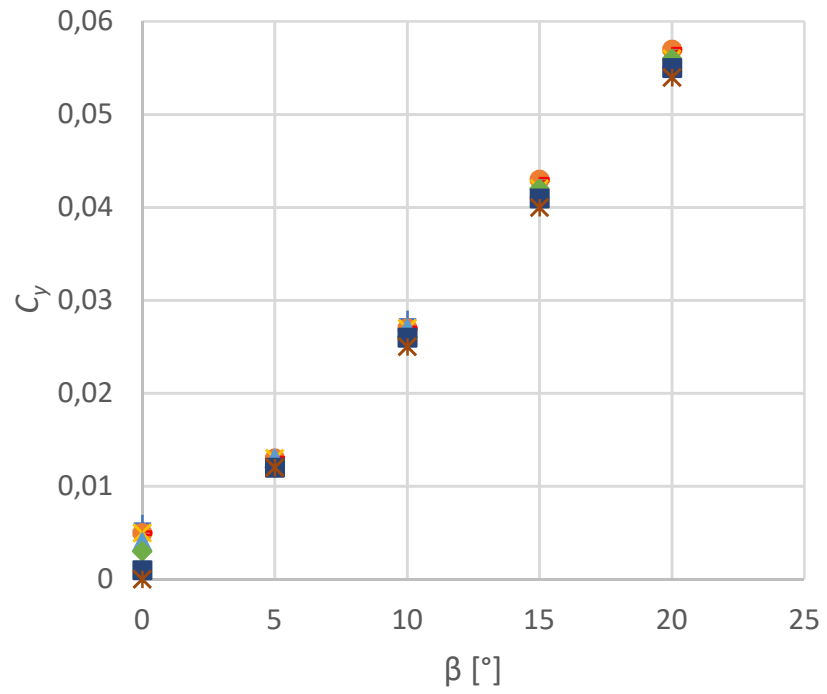

+ rudder angle $=35 \mathrm{deg}$

- rudder angle $=30 \mathrm{deg}$

- rudder angle = 25 deg

$\times$ rudder angle $=20 \mathrm{deg}$

$\Delta$ rudder angle $=15 \mathrm{deg}$

- rudder angle = 10 deg

rudder angle $=5 \mathrm{deg}$

* rudder angle $=0$ deg

Fig. 5. Lateral lift coefficient $C_{y}$ for the + rudder stern-plane configuration as function of drift angle $\beta$ for varying rudder angle $\delta$.

As an example of the calculation results, Fig. 5 shows the lateral lift coefficient $\left(C_{y}\right)$ as function of yaw/drift angle $(\beta)$ for varying rudder angle $(\delta r)$ for the + rudder stern-plane configuration. As shown in Fig. 5, the lateral lift coefficient $\left(C_{y}\right)$ increases with increasing drift angle $(\beta)$. Furthermore, for a given drift angle, the lift coefficient $C_{y}$ increases with increasing rudder angle. 


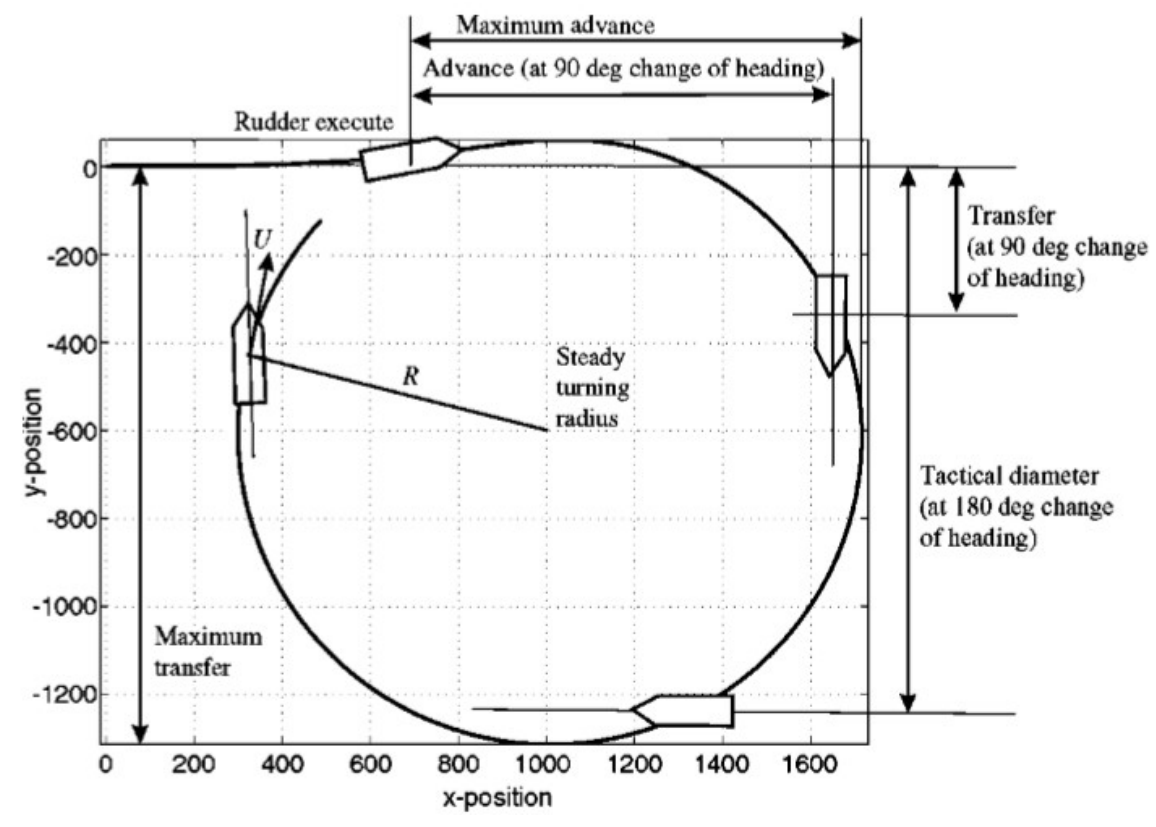

(a) Fossen [9]

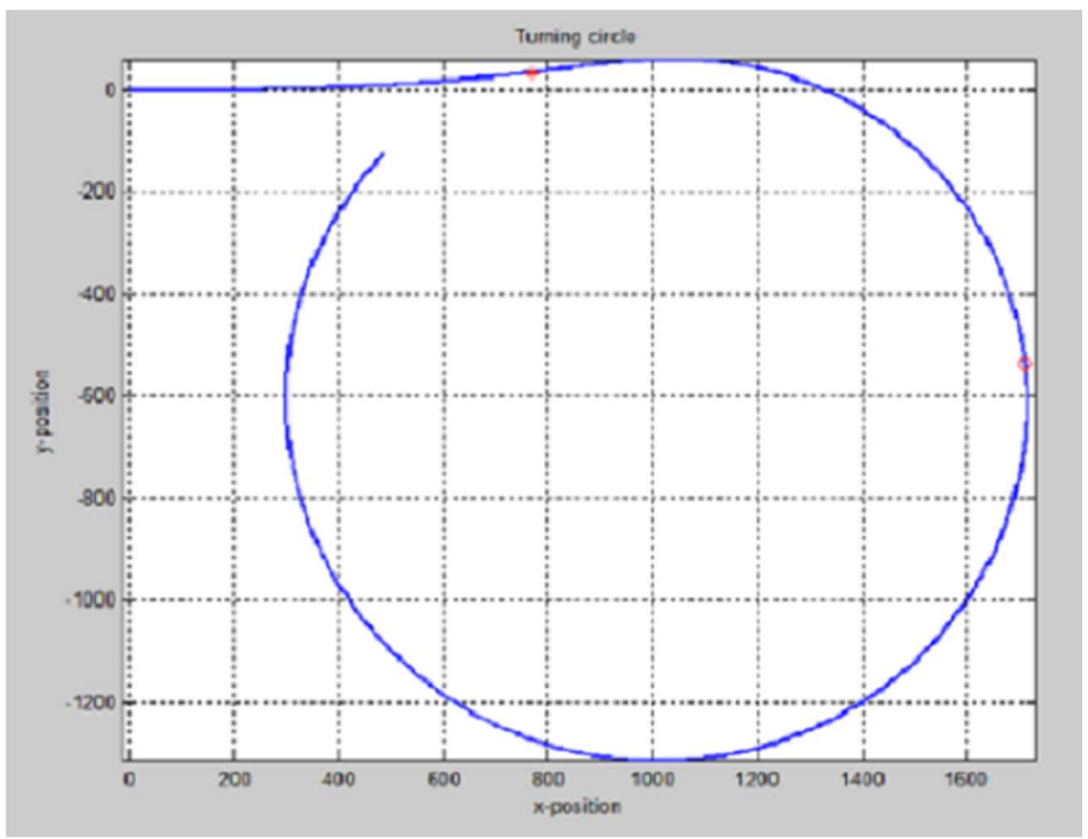

(b) Present study

Fig. 6. Comparison between turning circle calculated by Fossen [9] (a) and that obtained from the present study (b). 
To obtain the turning circle [18] for a given rudder-stern plane configuration and rudder angle as well as yaw angle, the equations of motions (1) were integrated numerically using in Matlab implemented Eulerian method. The results were verified using those reported in [9]. Figure 6 shows a comparison between the turning circle reported in [9] and that obtained from the present study. The calculation results are summarized in Table 3 . Table 3 shows that there are no differences between the results reported in [9] and the present results.

Table 3. Comparison between turning circle parameters calculated by Fossen [9] and those obtained from the present study.

\begin{tabular}{|l|c|c|}
\hline & Fossen [9] & Present study \\
\hline Rudder execute $(x$ coordinate) & $769 \mathrm{~m}$ & $769 \mathrm{~m}$ \\
\hline Steady turning radius & $711 \mathrm{~m}$ & $711 \mathrm{~m}$ \\
\hline Maximum transfer & $1315 \mathrm{~m}$ & $1315 \mathrm{~m}$ \\
\hline Maximum advance & $947 \mathrm{~m}$ & $947 \mathrm{~m}$ \\
\hline Transfer at 90 degrees heading & $534 \mathrm{~m}$ & $534 \mathrm{~m}$ \\
\hline Advance at 90 degrees heading & $943 \mathrm{~m}$ & $943 \mathrm{~m}$ \\
\hline Tactical diameter at 180 degrees heading & $1311 \mathrm{~m}$ & $1311 \mathrm{~m}$ \\
\hline
\end{tabular}

\section{Results and Discussion}

The turning circle for each combination of rudder angle $(\delta r)$ and drift/yaw angle $(\beta)$ as shown in Table 2 can be plotted and the tactical diameter, transfer, advance etc. can be calculated. For example, Fig. 7 shows results of the turning circles with rudder angle of $10^{\circ}$ and yaw angle of $0^{\circ}$ for the,$+ \mathrm{x}$ and y configurations projected in the $\left(x_{p o s}, y_{p o s}\right)$ plane. Figure 7 clearly shows that the $\mathrm{x}$-configuration gives the smallest turning circle radius.

In addition, Figs. 8, 9 and 10 show the turning circles in the $\left(x_{p o s}, y_{p o s}, z_{p o s}\right)$ space with the same rudder angle and drift angle as shown in Fig. $7\left(\delta r=10^{\circ}\right.$ and $\left.\beta=0^{\circ}\right)$ for the,$+ x$ and $y$ configuration, respectively. Figure 8 shows that for the + configuration the turning circle remains in the same horizontal plane, as expected, because the vertical lift coefficient $C_{z}$ is zero. On the contrary, the vertical lift coefficients of the $\mathrm{x}$ and $\mathrm{y}$ configurations are non-zero. Therefore, as shown in Fig. 9 (the x configuration), the submarine dives to a depth of $4 \mathrm{~m}$ below the initial position and then comes upward while circling to a position $2 \mathrm{~m}$ above the initial position. Similarly, for the y configuration (Fig. 10), the submarine dives $10 \mathrm{~m}$ below the initial position and then comes upward while circling until $5 \mathrm{~m}$ above the initial position.

Table 4 summarizes the results of tactical diameter for the case $\beta=0^{\circ}$. Table 4 shows that for all rudder stern-plane configurations, the larger the rudder angle, the smaller the tactical diameter, as expected. Furthermore, for all rudder angles, the $\mathrm{x}$ configuration gives the smallest tactical diameter (compared to the + and y configurations). Similar observations are also applied for the transfer, advance and radius of the turning circle.

Results for the turning circle are compared with the criteria given by the IMO resolution MSC 137 (76) for surface ship because there are still no corresponding criteria for submarine. Results of calculations show that to comply with the above IMO criteria, the smallest rudder angle is $25^{\circ}, 10^{\circ}$ and $20^{\circ}$ for the + , $\mathrm{x}$ and y configuration, respectively. 


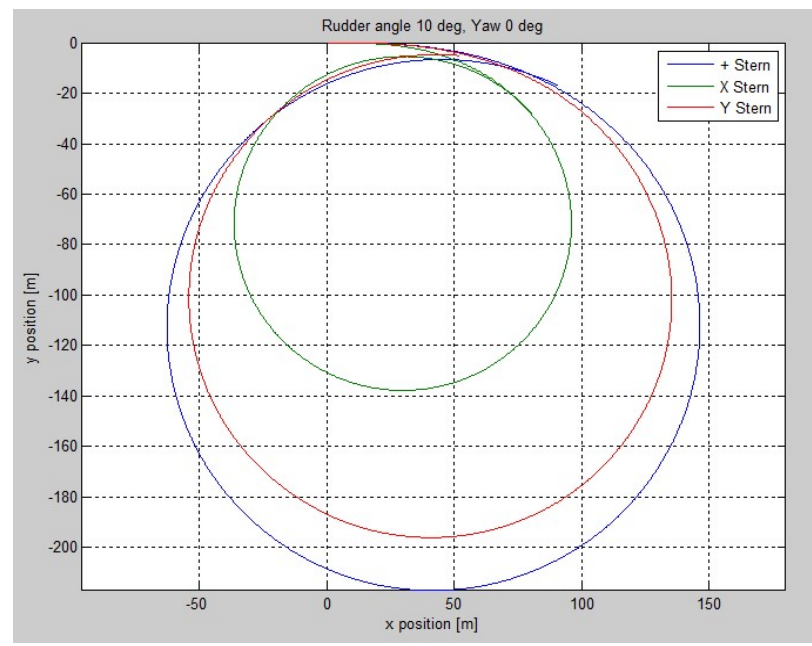

Fig. 7. Turning circles for rudder angle $\delta \mathrm{r}=10^{\circ}$, yaw $\beta=0^{\circ}$.

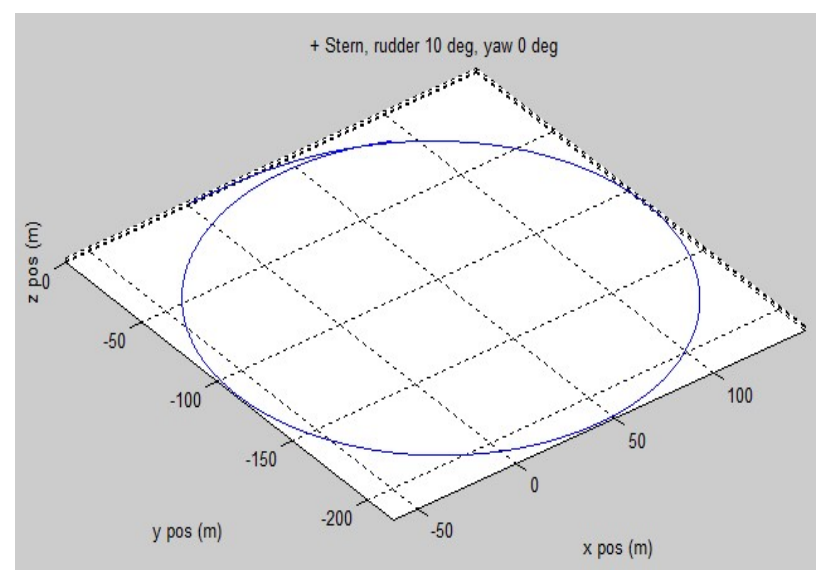

Fig. 8. Turning circle $\left(x_{p o s}, y_{p o s}, z_{p o s}\right)$ of the submarine for the + rudder stern-plane configuration with rudder angle $\delta \mathrm{r}=10^{\circ}$ and yaw angle $\beta=0^{\circ}$. In this case, the resulting $z_{p o s}=0$.

Table 4. Tactical diameter as function of rudder angle for different rudder stern-plane configurations $\left(\beta=0^{\circ}\right)$.

\begin{tabular}{|c|c|c|c|}
\hline \multirow{2}{*}{ Ruder angle $\left[{ }^{\circ}\right]$} & \multicolumn{3}{|c|}{ Tactical diameter [m] } \\
\cline { 2 - 4 } & +-stern & x-stern & y-stern \\
\hline 5 & 1210 & 810 & 986 \\
\hline 10 & 217 & 138 & 196 \\
\hline 15 & 146 & 69 & 113 \\
\hline 20 & 118 & 62 & 75 \\
\hline 25 & 106 & 44 & 59 \\
\hline 30 & 82 & 43 & 52 \\
\hline 35 & 62 & 32 & 41 \\
\hline
\end{tabular}




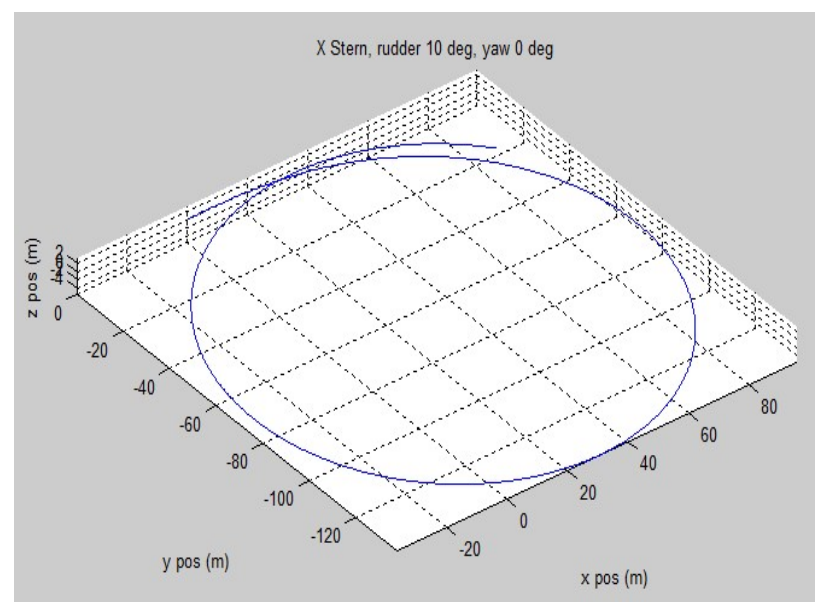

Fig. 9. Turning circle $\left(x_{p o s}, y_{p o s}, z_{p o s}\right)$ of the submarine for the $\mathrm{x}$ rudder stern-plane configuration with rudder angle $\delta \mathrm{r}=10^{\circ}$ and yaw angle $\beta=0^{\circ}$.

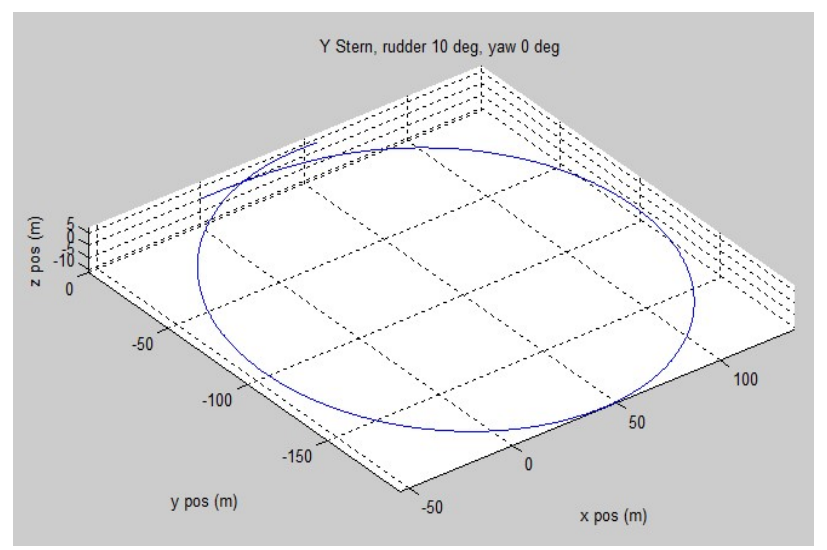

Fig. 10. Turning circle $\left(x_{p o s}, y_{p o s}, z_{p o s}\right)$ of the submarine for the y rudder stern-plane configuration with rudder angle $\delta r=10^{\circ}$ and yaw angle $\beta=0^{\circ}$.

\section{Conclusion}

The rudder stern-plane configuration of a submarine plays a key role in determining the submarine manoeuvring performance. In the present study, three rudder stern-plane configurations $(+, \mathrm{x}$ and y configuration) were investigated to obtain optimum manoeuvring characteristics of a midget submarine. For all configurations, the larger the rudder angle, the smaller the tactical diameter, transfer and advance. For the + configuration, the smallest rudder angle to result in the tactical diameter, radius and advance that comply with the IMO resolution MSC $137(76)$ is $25^{\circ}$, while for the $\mathrm{x}$-configuration $10^{\circ}$ and for the y-configuration $20^{\circ}$. The smallest tactical diameter, transfer and advance were obtained by using the $\mathrm{x}-$ configuration, which is considered as the most optimum rudder-stern plane configuration. 
Putri Virliani thanks the Ministry of Research, Technology and Higher Education of the Republic of Indonesia for the scholarship Pascasarjana Dalam Negeri 2015-2017.

\section{References}

[1] R. Burcher, L. Rydill, Concepts in submarine design, Cambridge Univ. Press, (1994)

[2] M. Moonesun, P. Charmdooz, General Arrangement and naval architectural aspects in midget submarines, 4th Int'l Conf. Underwater Sys. Tech.: Theory Appl., Shah Alam, Malaysia (2012)

[3] Erwandi, M. Jefferson, C. S. Jati, D. Wahyudi, Nurwidhi, Desain dan uji hidrodinamika kapal selam mini berbobot 133 ton, Prosiding InSINas, pp. 1-6 (2012)

[4] M. R. Utina, A. Syafiul, B. Ali, Numerical and experiment investigation of lift performance over hydroplane of submarine, J. Subsea Offshore Sci. Engrg., 5 (2016)

[5] M. Mackay, Wind tunnel experiments with a submarine afterbody model, Tech. Memorandum, Defence Res. Development, Canada (2003)

[6] T. I. Fossen, Guidance and control of ocean vehicles, John Wiley \& Sons Ltd., New York (1994)

[7] R. D. Blevins, Formulas for natural frequency and mode shape, Krieger, Florida (1979)

[8] Toxopeus, Practical application of viscous-flow calculations for the simulation of manoeuvring ships, PhD tesis, Maritime Res. Inst., Netherlands (2011)

[9] T. I. Fossen, Hand book of marine craft hydrodynamics and motion control, Norwegian Univ. Sci. Tech., Trondheim, Norway (2011)

[10] Feldman, DTNSRDC revised standard submarine equations of motion, Tech. Rep. Carderock Div. Naval Surface Warfare Center, Maryland, USA (1979)

[11] H. Zhang, Y. Xu, H. Cai, Using CFD software to calculate hydrodynamic coefficients, J. Marine Sci. Appl., 9 pp. 149-155 (2010)

[12] P. Virliani, Pengaruh bentuk after body terhadap maneuvering kapal selam mini, M.Sc.thesis, Fac. Marine Tech., ITS Surabaya, Indonesia (2017).

[13] H. K. Versteeg, W. Malalasekera, An introduction to computational fluid dynamics: the finite volume method, Longman Scientific, Harlow, UK (2007)

[14] F. R. Menter, Two-equation eddy-viscosity turbulence models for engineering applications, AIAA J., 32(8), pp. 1598-1605 (1994)

[15] J. E. Bardina, P. G. Huang, T. J. Coakley, Turbulence modeling validation, testing, and development, NASA Tech. Memorandum 110446, Ames Res. Center, Moffett Field, California, USA (1997)

[16] J. D. Anderson Jr., Computational fluid dynamics: the basics with applications, McGraw-Hill, Inc., New York (1995)

[17] W. L. Oberkamp, T. G. Trucano, Verification and validation in computational fluid dynamics, Prog. Aerospace Sci., 38 pp. 209-272, Pergamon Elsevier (2002)

[18] M. Renilson, Submarine hydrodynamics, Springer Briefs Appl. Sci. Tech. (2015) 